Robin Tyson*

\title{
The South African media's (re) colonisation of Namibia
}

\begin{abstract}
This paper seeks to reveal the patterns of power, influence and ownership that South African media houses are having over Namibians and Namibian media outlets. The hypothesis is that there has recently been an increased interest in Namibia as a source of further revenue for South African media businesses as well as an opportunity for further strengthening ties of cultural and language issues between the two countries. In addition there might also be increased opportunities for South African political perspectives to be further advanced through linkages with Namibian media outlets.

The paper further seeks to expand academic discourse to include those countries, such as Namibia, living in South Africa's cultural and economic shadow, and, in a larger sense, looks at the increasingly regional and even nature of media systems in Africa.

It tries to move these discussions into everyday discourse, as opposed to the margins, where, as McMillin (2007:68) says:

we fail to understand the incredible impact of colonialism on the development of their media systems, the regional influence of these systems, and the unique character they take on as they assert their postcolonial identities and meet the challenges of globilization.
\end{abstract}

The research refers to the unique position of Namibia, having been, firstly, a German colony, and, later, a South African 'administered territory', and makes reference to the implications this had on the shaping and control over the media environment.

The findings reveal an increase in South African influence and shareholding over Namibian media companies and content. This parallel has strengthened economic ties with South Africa, and in particular the influence of South African retail chains and their stock levels of Namibian versus South African publications.

Key words: Influence, Namibian media outlets, ownership, power, South African media houses.

*Robin Tyson is a lecturer in the Department of Media studies at the University of Namibia. Contact details: rtyson@unam.na. P O Box 98803, Windhoek, Namibia. Tel: 0926461206 3194; Fax: 0926461206 3806; Cell: 09264812628321 


\section{COLONIAL STRUGGLES}

After a long and bitter struggle, Namibia gained its independence from South Africa on 21 March 1990. The event itself was widely covered by the media, with South African television, for the first time, relaying programmes directly via the newly formed Namibian Broadcasting Corporation, from the Independence Stadium in Windhoek.

It was an historic moment, for until this time South West Africa had been in the political and cultural grip of South Africa, and the electronic media had, to a large extent, been barely distinguishable clones of their South African counterparts.

Thus, the evening schedules of $S W A B C T V$ before independence were filled with Afrikaans programmes from the $S A B C$. This included programmes such as Orkney Snork Nie and Spies en Plessis. Similarly, the evening news bulletins would be dominated by alternating English and Afrikaans evenings, with Afrikaans playing the major role. Early SWABC TV news bulletins in the 1980's would have three Afrikaans bulletins (Mondays, Wednesdays, and Fridays) and only two English bulletins (Tuesdays and Thursdays).

So, when South Africans viewed the events of 21 March 1990 live from the Namibian Broadcasting Corporation on South African television screens, it was a clear message that things were not to be the same. The balance of (media) power had significantly shifted.

Not everybody, however, was impressed by the transmission. Richard McNeill of the South African Sunday Times (1990-03-25), spoke of cameramen 'clearly shellshocked amid the melee of personalities, ranging from Nelson Mandela ... and Jesse Jackson .. to the UN secretary-general Javier Perez de Cuellar'.

More astutely, Ian Gray of the The Star (1990-03-26), noted that:

The point is not that the $N B C$ 's coverage was bad but that the $S A B C$ was not there in person, so to speak ... It was history in the making, and the $S A B C$, capable of giving golf and road-running blanket coverage, could easily have managed the independence ceremony ... It would have been the ideal occasion for the $S A B C$ to redeem itself, literally in the eyes of the world.

The derogatory comments towards Namibia's fledgling television service can, with hindsight, be seen as neo-colonial utterances, the underlying tone being one of arrogance - that South Africa is better than Namibia, even when covering a Namibian event!

The connection between the colonial power and its slave (South West Africa was a 'mandated' territory under the League of Nations) had, of course, developed over many years. The first broadcasts originating from South West Africa were in 1956, when the $S A B C$ appointed a regional news representative in the country.

The $S A B C$ went on to establish three ethno-linguistic radio services in Namibia, broadcasting in three languages - Otjiherero, Damara/Nama and Oshiwambo. It should be remembered, however, that these services were part of a greater South African strategy designed to divide and rule the nation (and its territories, such as Namibia).

In particular, it followed the stated objectives to become 'another battalion in South Africa’s ideological and war machine’ (Amupala, 1996:2). The differences, 
therefore, between races, and in particular amongst races, were emphasized by the broadcasting of material that promoted cultural traditions and, in particular, music.

Ironically, the $S W A B C$ transcription service, which even today serves as a rich resource of music from various cultural groups in Namibia (recorded on location and at great expense), has today all but died, and the fostering and promotion of traditional culture has been severely diminished. The notion of the (new) Namibian nation in a sense overrode these cultural distinctions, leading to a predominance of national, as opposed to regional or ethno-linguistic programme content.

It was with the adoption of the United Nations Resolution 435 in 1978 that the broadcasting environment changed, and the quasi-independent SWABC (South West African Broadcasting Corporation) was formed under Proclamation A-G 16 (the A-G standing for Administrator-General, who was the de facto representative of the South African occupying regime).

The structure of the Corporation was, however, very closely modelled on that of the $S A B C$, and in particular there were similar infiltrations at a high managerial level of Afrikaner Broederbond members.

However, even in the early days of the Corporation, there remained the colonial hangover from South Africa's apartheid thinking, despite the fact that many notorious South African acts had by that stage all but disappeared from the South West African law books.

In particular, the radio division of the $S W A B C$ remained organized under two distinct 'controllers'. The one was the Controller: AEG (Afrikaans, English, German) - the traditional 'white' services, the other was the Controller: Language Services (Oshiwambo, Otjiherero, Damara/Nama, Rukavango, Lozi, Setswana). The latter, interestingly, despite being controller of 'black' radio channels, was a white male.

Television also arrived late in Namibia, a domino effect spurred by the late arrival of television in South Africa. Amupala (1996) postulates reasons for this, one being the lack of the ability of the $S A B C$ to produce programmes in the Afrikaans language (and thus the medium would be dominated by English content) as well as 'the possibility of screening scenes portraying inter-racial relations'.

When television did come to Namibia, in 1981, it was initially a relay from the $S A B C$, with cassette services flown in daily for broadcasts. This system of programme distribution using video cassettes was later extended to other areas of Namibia, such as Walvis Bay and Oshakati. The latter was a major base for South African troops operating in the country and it was thus strategically vital that the 'boys on the border' also receive the morale-boosting South African programme content.

In addition, of course, it would have a useful influence in the 'hearts and minds' campaign also being implemented at the time, in which the local population would be indoctrinated to support the South African regime and culture (in particular the white culture).

In looking at this seeming dominance of cultural imperialism, we need to talk, as Dissanayake (2006:39) does, of cultural imperialism:

In order to convert the idea of cultural imperialism into a more productive tool of social analysis, we need to explore its inner dynamics in the light of contemporary cultural experiences, relate it to the forces of global capitalism in a more complex manner, and tie it to the discourse of nationhood. 
This must include a mention of the political economy of both South Africa and Namibia, for this affects the media relationship and ownership patterns, as well as the flow of information between the two countries.

Attention must also be drawn to the fact that commercial media houses (such as the much praised Namibian newspaper) are also not without strong forces on editorial content - that which Duncan and Seleoane (1998:16) refer to as 'the market as censor'. They also note the current context of globalisation (Duncan \& Seleoane, 1998:16):

One of the earlier manifestations of the globalisation of information channels was justified in terms of the nation of a free flow of information that transcended national boundaries, in the interests of furthering democracy internationally. Media commentators have analysed how this concept was used politically, in the process laying bare the assumptions underlying this supposedly 'natural right'

McMillan (2007:6-7) further notes:

After independence, the task of the postcolonial media system was to forge a new identity for the nation that had been "purified" of the colonial experience. The battle over what emerged becomes a fascinating study of the role of state-owned and private media in constructing identities that resonate with local cultural bases and that are mobile and lucrative in the marketplace.

\section{LANGUAGE ISSUES}

The history of broadcasting in Namibia before independence is one of dependence on South African content. It was only in 1956 that a 'regional news representative' was appointed in the territory, but with a special emphasis on reporting aimed at, in particular, the white farming community in the country.

Even as late as 1986, the Lozi service of the $S W A B C$ was broadcasting from Johannesburg, and not from its (present) base of Katima Mulilo in the Caprivi.

'Television was introduced to Namibia only in 1981. Initially it was a relay from the $S A B C$, or as a cassette services, flown in daily for rebroadcast. This service was extended to Oshakati and Walvis Bay and broadcasts were usually a day or two late' (Amupala, 1996:4).

One of the first steps of the national broadcaster on its creation at independence was to promote vigorously the new official language, English. Indeed, the 1991 NBC act (section 3d) noted in particular the need 'to promote the use and understanding of the English language.

The end result was a dropping of Afrikaans content from NBC television schedules, and, when indigenous television languages were introduced, neither Afrikaans nor German were included as news broadcasts.

Ironically, the neglect of Afrikaans in particular by the national broadcaster has led to the burgeoning growth of commercial and community radio stations focusing on the language as well as scheduling Afrikaans music (predominantly by South African artists) in their mix. Radio Kudu, Radio Kosmos_and the community religious station Kanaal Sewe (a station with the largest transmitter, apart from NBC, reaching across Namibia) are but some of the examples. 
Again, the links with South Africa are clear. Radio Kosmos itself was formed as an alliance with a South African based station, and originally much of the broadcasting originated from Pretoria. The Namibian Communications Commission however decided that an essentially South African station broadcasting in Namibia, and using up valuable FM frequency resources, was not acceptable, and the station was obliged to become wholly Namibian in its staffing, with the construction of a small studio in a local shopping centre - although this later became a grander affair on one of the city's major intersections.

At the opening of the new studio, then Minister of Information and Broadcasting, Theo-Ben Gurirab, was quoted as stressing that the station was a demonstration of the mixed economy and ownership as enshrined in the Namibian constitution - and spelled out in the Namibian Government Information Policy (1991:4) - (The Namibian, 2001-07-20):

Article 98 of the Namibian Constitution provides for a system of mixed economy. In line with this principle of mixed economy, the country's information policy allows for a pattern of mixed ownership of the mass media, namely, ownership by private individuals or groups, on one hand, and by the state, on the other.

Gurirab (The Namibian, 2001-07-20) also noted that, 'although Kosmos Digital will mainly focus on the Afrikaans-speaking community, keeping its language and culture alive, it offers Namibians wider choices and keeps competitors on their toes'.

Ownership of the station has also revealed that, although two local entrepreneurs (Kollie van Coller and Helmy Hitula) are the main shareholders, a remaining 23 percent is held by South African investors.

All of these stations are flourishing affairs, with some (Radio Wave, Radio Energy) even appearing on the continent-wide DSTV bouquet (Audio channels 167 and 168).

In addition, there are other stations that are available on the internet through audio streaming.

So, there are isolated instances of local broadcasters penetrating the Africawide market. However, the predominant media traffic is from South Africa to Namibia.

In addition, Namibians are now so addicted to satellite channels that when a new terrestrial free-to-air television channel was introduced viewers were confused about how to receive it, asking what (satellite) channel it was on.

The national broadcaster, however, continued its strong determination to sever South African ties. Soap operas on NBC TV continue to be dominated by programming from Central and South America. These include Gardener's Daughter; When you are mine and Second Chance.

Currently, according to Koenderman (2008:40), Namibia has 50 TV receivers per 1000 population, and 137 radio sets per 1000 .

Afrikaans and German were the only two major Namibian languages left out when language news bulletins (Oshiwambo, Otjiherero, Damara/Nama, Silozi, Rukavango) were introduced on $N B C T V$. The bulletins, originally broadcast in prime time slots each evening, are now, due to increased commercial pressures on the $N B C$, relegated to early morning time slots: 07:00 - 08:00 each weekday morning. At one stage there were four news bulletins each evening - two in English (20:00 and 22:00) and two language bulletins at 19:30 and 20:30. 
According to Larsen (2007:81) Cosmos Digital Namibia (Kosmos Radio) 'is currently negotiating with NBC Television to launch a daily Afrikaans news bulletin to complement the other language services'.

\section{SATELLITE BROADCASTING IN NAMIBIA}

Direct broadcast satellite transmission allows the flow of messages across national borders, and national governments are fearful of the implications of this flow for national identity and cultural integrity. Loss of control over the definitions and circulation of national culture translates into loss of power and control over national boundaries - a reason for hegemonic anxiety (McMillin, 2007:103).

It may be said that the Namibian government is either not fearful of these implications, or, more intelligently, has initiated them, by essentially owning them. The largest satellite broadcaster in the country, DSTV, has a major shareholding from Kalahari Holdings, a SWAPO company.

However, the Vivid bouquet (introduced by Sentence or Sentech? in South Africa after the now defunct analogue Astrasat) now offers Namibians a viable (and free) alternative to DSTV. For Namibians struggling with so many increased costs (petrol, food, interest rates) the idea of free satellite television is tempting.

Official Sentech 'Vivid' decoders have now been replaced by so-called 'freeto-air' decoders, selling for less than R700 at various Namibian outlets. The range of channels available (with no monthly subscription payable) is staggering, with $S A B C$ 1,2 and 3, along with etv, being the most popular. Nevertheless, the high quality content from Botswana TV, as well as specialised channels such as CNBC, France 24, Press TV (Iran) and SABC International, allow viewers a wide range of free programming, along with a multitude of religious channels (both Christian and Muslim).

The other advantage is that these broadcasts originate from the same satellite (PAS 7/10) as those on DSTV, thus making it relatively easy to simply unplug the DSTV decoder and plug in the free-to-air decoder instead.

The PAS 7 footprint stretches throughout Southern Africa, including major centres such as Windhoek (Namibia), Lusaka (Zambia) and Harare (Zimbabwe) and Blantyre (Malawi) (Hadland, et al. 2006:157).

Figures for how many Namibians have purchased these decoders remain elusive, although advertisements for the equipment appear almost daily in local newspapers. Even a respected South African media publication found it impossible to obtain numbers when attempting to establish the viewership for the newly launched SABC International - as Pampalone (2008:38) states:

only to be seen by those 65000 people who had a decoder ... For the record, this generous number came from the $S A B C$, which bandied about estimates of between 6000 and 60000 during various conversations but ended up with an official count of 65000 . Meanwhile, Sentech refused requests from Empire to confirm how many viewers it had or where they were located, saying such information was 'not for public consumption'. 
DSTV have retaliated with a series of ever-cheaper bouquets. The original full package (over R400 a month) has now been broken down into smaller bouquets, the cheapest ('Easy View') costing only R17 a month! DSTV of course are not only facing competition from the Vivid platform, but also a new entrant into the Namibian satellite market, GTV. During 2007, viewers were so incensed with the loss of rights to UK soccer matches that a viewers association was formed, and a demonstration held (with police in attendance) at the local Multichoice headquarters, where several angry viewers publicly cancelled their DSTV subscription. They called themselves, pointedly, the 'Rest of Africa' group, incensed with Multichoice's distinction between South Africa and the 'Rest of Africa' in their scheduling. This, of course, also reveals the continued linkage to South Africa in the minds of subscribers, or, perhaps, the fear of Namibian viewers being seen as 'African' rather than 'South African'.

GTV, however, has required viewers to purchase a new decoder, along with a new (or repositioned) satellite dish. Perhaps for this reason local bank Nedbank has been brought in to provide financing for those viewers wishing to change (or add) GTV to their bouquet. The slogan of GTV is 'Give your TV a new life.'

Even where local media are strong, the content sometimes continues to be dominated by South Africa. Discussions abound on the performance of the Springbok rugby team, South African artists such as Bok van Blerk and Steve Hofmeyer and South African news such as load shedding and crime.

In the more formal news bulletins information originating from South Africa tends to dominate, with odd stories about the Minister of Safety and Security (South African) or minister of Foreign Affairs (South African), without reference to the fact that they are, essentially, figures from a foreign country.

\section{LOCAL CONTENT}

The Namibian communications commission Act of 1992 (Act 4) provides for the establishment of the commission, which regulates broadcasting in the country. In particular it encourages programmes that stimulate a shared national consciousness and identity and also encourages the employment of local entrepreneurs/professionals where possible, though the Act does not provide for any mechanism to monitor adherence, nor does it specify any quotas for local content.

The rulings of the Commission, particularly with regard to Radio Energy and Katutura Community Radio (KCR), have thrown doubt on its ability to be nonpartisan in ensuring diversity of broadcasting. A case study was an event that took place in 1996, when the NCC (Namibia Communications Commission) told KCR that it would 'have to move to a different frequency ... Following an international outcry, the NCC allowed KCR to remain at 106.2 and ordered Radio 100 to move to a different frequency' (Lush \& Kandjii 1998:60).

The end result was that the commercially viable frequency (100FM) was given to the commercial station, and the more 'obscure' frequency (106.2FM) given to the community radio station. The fact that Radio Energy had a majority shareholding from Kalahari Holdings (the ruling party's business arm) also underlined the lack of objectivity in allocating frequencies. 


\section{OWNERSHIP PATTERNS}

In general there has been a regional increased centralisation of ownership - as well as shareholdings, in particular from South Africa. This follows a broad international pattern (Duncan \& Seleoane 1998:18):

The commercial media today are characterized by an increasing concentration of ownership on a worldwide scale, growing cross-media ownership in countries that allow it - and extreme pressure on the governments that don't - and a depletion of smaller local media concerns as entry-level and running costs increase.

Unfortunately, it also means that fewer people 'are engaged in the control of more and more information’ (Duncan \& Seleoane 1998:18).

'In developed countries, the media become less and less diversified as conglomerates buy up smaller groups’ (Emdon,1998:161).

The 1992 Namibian government policy provides an overall framework for issues related to broadcasting and print media. With regard to ownership the policy stresses a pattern of mixed ownership of the media, allowing for both privately owned and para-statal media establishments.

It does, however, allow for government ownership of media in order to allow coverage of, and the involvement of, activities in rural areas. In addition it warns of the non-independence of private media, noting that it is, according to the Namibian Information Policy (1991:5):

subject to controls and 'censorship' by the owners, advertiser, and, of course, the clientele which the particular publication or film intends to hold (...) There is no doubt that the media in Namibia have tended to be partisan (...) not always balanced in their approach and coverage.

This has also been reflected in more recent statements by, amongst others, the Minister of Information and Broadcasting as well as the former Prime Minister, Dr Hage Geingob (reference?), who warned journalists to 'tell the truth and nothing but the truth', and stated that, in his opinion, 'the press is there to report positively on events'.

New Era newspaper was therefore established in 1992, as a Government newspaper. Its aim was to place special emphasis on community-related issues, particularly issues in the rural areas of Namibia and issues of national interest and government related matters. However, in his study on Media Ownership and Legislation in The Republic of Namibia 1990-2007, Martin Buch Larsen (2007:33) points out that 'as long as there are no specific quotas or percentages mentioned or a mechanism to monitor these, this intention remains only intent'.

Ironically there had been no direct Government publication before independence although, obviously, many newspapers were taking an actively proSouth African political line, supporting troops on the border, and towing the editorial 
line of the South African apartheid regime as well as the local South West Africa Territory Force.

That linkage with South Africa, however, is resurgent. Several recent developments have started to dramatically change the local media environment. In particular the 49 percent shareholding in Democratic Media Holdings by Media 24, under the international conglomerate Naspers. $\mathrm{DMH}$, formed under the management of Dirk Mudge (who himself has strong affiliations to the Democratic Turnhalle Alliance), now publishes a range of newspapers in Namibia, including the wellestablished Afrikaans and German publications, Die Republikein and Allgemeine Zeitung.

In addition the company has recently established the Namibian Sun, modelled strongly on the South African Daily Sun, with similar layout, and even borrowing certain features from the South African edition. The publication, like its South African counterpart, targets young black readers, with columns on entertainment and gossip, as well as a regular pull-out section of SMS messages.

John Meinert Printers, a major printer for local newspapers, is also under the wing of $\mathrm{DMH}$, but the most dramatic development in the past year has been the incorporation by DMH of Radio 99, now re-branded as Namibia Live FM 99.

This means that DMH, with that strong shareholding from South Africa's Media 24, are the dominant players in the Namibian media market, with interests in local newspapers, targeted at a wide cross-section of society, as well as a printing press, and, now, radio.

Namibia's ruling political party, SWAPO, is also actively involved in the media. This is in addition to their obvious interests in and, to a certain extent, control over bodies such as the Namibian Broadcasting Corporation, New Era, and the government press agency, NAMPA. The Minister of Information and Broadcasting (now the Minister of Communications), directly appoints the board members for each of these three institutions, along with the board of the Namibia Communications Commission.

Radio Energy (100 FM) was originally owned by two German citizens (one of whom, R???. First name here Lange, also owned Namibia's first private radio station, Radio 99). Between 2002 and 2003, however,they were bought out by Kalahari Holdings (the investment arm of SWAPO), who now wholly own the station. While there is no overt politicisation of the station, it was noticeable that, during the last election campaign, songs (a mixed rap version featuring former President Nujoma and then incumbent Pohamba) were prominently featured as part of the music compilation on the station.

SWAPO are also involved in another venture with a major South African concern, Multichoice. It was established in 1993, with a majority shareholding from Kalahari Holdings and a minority holding from MultiChoice Africa. Again, the linkages with the other major South African investment, that of Media24 into DMH, noted above, are clear. Media24, or Naspers, were the ones to start an electronic subscription service named M-Net. That was later to be called MultiChoice.

So the linkages (through Media24) between DMH and MultiChoice become increasingly clear, leaving other publications (The Namibian, Informante) out in the cold. This is despite the fact that The Namibian, in particular, was the newspaper that supported the liberation struggle of the country. The name of the newspaper itself proved to be highly antagonistic to the South African regime in a period when the country was called South West Africa or, grudgingly, South West Africa/Namibia. 
The result is that, today, there remains a serious boycott by government of The Namibian in particular. The ban, initiated and later passed by cabinet, forbids all government institutions from buying The Namibian. This was later followed by a ban on government advertising in the newspaper, giving such tenders and advertisements to state owned publications only and, ironically, Die Republikein, the very publication allied to the DTA (the former South African backed opposition party to SWAPO).

Another new development is the involvement of South African satellite broadcasters in the local television scene. With the emergence of new satellite operators, including e-sat and Telkom, at least one (Telkom South Africa) has made inroads into the Namibian television operations, with a shareholding in Namibia's only commercial television station, One Africa TV.

The Chairman of Telkom Media, Connie Molusi (The Namibian, 2007-11-23), was quoted as saying that One Africa 'must rate as one of the best free-to-air television stations on the African continent' However, new developments, including the scaling back by Telkom of investment in Telkom Meida, might put such linkages in doubt (Gedye \& Joubert, 2008:3).

One Africa TV itself is an offshoot of the now defunct TV Africa, which operated in several African countries. The station has now proved itself to be financially sustainable, showing a variety of predominantly entertainment programmes (both soccer and soap operas), but also transmitting a nightly television news bulletin, launched in 2007.

However, on launch, The Namibian (2003-11-11) reported that the station, when launched, started broadcasting 'new programme content acquired from suppliers in South Africa ... [including] ... South African soap operas "Isidingo" and "7de Laan", as well as the CAF soccer cup and $S A B C$ investigative programme "Special Assignment”'.

Currently, Paul van Schalkwyk, founder and managing director of One Africa, believes the station has more than 400000 viewers watching an average of three and a half hours of programming per evening (The Namibian, 2007-11-23). The station reaches major towns in Namibia, including Eenhana, Gobabis, Grootfontein, Henties Bay, Karasburg, Karibib, Katima Mulilo, Keetmanshoop, Luderitz, Mariental, Okahandja, Okakarara, Omarurur, Ondangwa,Ongwediva, Oranjemund, Oshakati, Otjiwarongo, Oshikango, Rehoboth, Rosh Pinah, Rundu, Swakopmund, Tsumeb, Usakos, Walvis Bay and Windhoek.

One of the last radio frequencies granted in Windhoek (Windhoek Paris FM) by the Namibian Communications Commission (107.9) was given to Radio France International. Again, legislation restricted the foreign ownership to 49 percent (Radio France International), with the 51 percent local shareholding given to the Namibian Broadcasting Corporation (51 percent) (Larsen 2007:123). The content of the station is predominantly in French, with some hours of each day's relay from France being broadcast in English. There would be some criticism of the NCC in not closely following the NCC Act by forcing this station to broadcast local content (and, of course, provide local employment) which they did in the case of Kosmos Radio some years previously.

Section 17 ( $d$ \& e) of the NCC Act states clearly that the duties of a licence holder are to:

encourage the development of Namibian expression by providing a wide range of programs that reflects Namibian attitudes, opinions, ideas values and artistic creativity by displaying Namibian talent in 
entertainment programs in so far as it is practicable to do so and with due regard to the nature of the service pertaining to the license holder ...to serve the needs and interests and reflect the circumstances and aspirations of Namibian Men. Women and children in a multi-cultural and multi-racial Namibian society.

It could be strongly argued that the allocation of a valuable frequency on the FM band in Windhoek to a station such as Radio France International goes against these principles. Indeed, it applied for a licence in 1999, 'but the Namibian Communications Commission rejected it because it did not meet the NCC's shareholding requirements. The NCC compelled the two to establish a joint venture and to increase local content to 30 per cent before it would grant a licence' (The Namibian, 2002-03-04).

Other commercial radio stations have multiple shareholdings. Some stations, according to Larsen (2007:143):

continue to see a number of their shares held by mainly South African (and other foreign) citizens. Most station owners and managers are from the 'white and well-established' community in Namibia and South Africa, meaning the exploitation of the commercial airwaves is in the hands of a small minority.

There are two reasons for the lack of local ownership (and in particular black ownership) of the media. Firstly, as noted by Mason (2001:88), there is a lack of 'black' capital in the country. Secondly, there are historical ties with South Africa, as well as the continued economic domination by the South African economic forces over those of Namibia.

\section{SOUTH AFRICAN SOAP OPERAS}

One area in which the South African television industry has been highly successful is that of soap opera production and export. Both NBC TV and One Africa TV in Namibia show a variety of South African soapies, including Isidingo, Generations and 7de Laan. Indeed, on several occasions South African stars from Generations, for example, have visited Namibia and made an appearance at various functions.

There are other fascinating regional or international linkages that, in their way, underline Namibia's foreign policy through the choice of alliance. The national broadcaster, for example, relays CCTV (China Central Television), a government channel, on a daily basis, and, when a recent strike at the $N B C$ threatened to close the channel down, CCTV was used to fill the day's transmissions.

Similarly, a weekly publication, Southern Times - with an estimated readership in Namibia of just 2000 (Larsen, 2007:100) - was set up in 2004 as a 'counter' to the South African Sunday Times. It describes itself as 'The Newspaper for Southern Africa', but the website (www.southerntimes.com.na) is silent on the vision statement of the newspaper or its core values. A search reveals that the 'site is under construction'.

It is a joint venture of NamZim Newspapers (Pty) Limited between Free Press Printers in Namibia and Zimbabwe Newspapers Ltd in Zimbabwe.

Speaking in Namibia's National Assembly, then Minister of Information and Broadcasting, who?, announced that New Era (as 50 percent shareholders in the 
Larsen joint venture) had contributed N\$1 million - R1 million - and Zimpapers N\$1,4 million - R1,4 million (Dentlinger, 2005).

\section{SOUTH AFRICAN PRINT PUBLICATIONS}

Sonja Laden (2001:101) talks of the social change in the commercial black press of South Africa, entailing, among other things 'the ways the consolidation of a commercial black press in South Africa came to bear on the (re)production of individual selfhood and collective identity among black South Africans in urbanizing environments'.

This, naturally, will have a filtering down effect on Namibian black readers in particular, and their perception of self and identity.

A wide variety of South African publications are available in Namibia, particularly through the South African retail chains such as Checkers, Pick 'n Pay and the CNA - the latter has three branches in Windhoek alone. This domination of printed material distribution by the South African chain has led to difficulties for local publishers, who find it virtually impossible for their books to be made available locally, because the CNA decisions are made in South Africa: 'CNA's stores are all controlled from South Africa, so getting a local book carried in the local branch store is no easy task ... For small local publishers, large international chains can be impassable obstacles' (Wresch, 1996:40).

Nevertheless, there are exceptions, and the local branches of Pick ' $n$ Pay (which operate as 'Model Pick 'n Pay' in a co-operative agreement with a local business, Olthaver \& List) were aggressive in marketing a publication by local author Mathew Gowaseb during 2007. Copies of the book were available at all Pick 'n Pay branches throughout Namibia.

In addition, there are a variety of locally produced magazines available through South African supermarket chains (see below). Information collected at Maerua Mall and Auas Valley shopping centres, Windhoek, 7 May 2008.

\begin{tabular}{|l|l|l|l|l|l|l|}
\hline & Checkers & Clicks & C.N.A. & Pick 'n Pay & Spar & $\begin{array}{l}\text { Woermann } \\
\text { Brock }\end{array}$ \\
\hline The African & $\sqrt{ }$ & $\mathrm{X}$ & $\mathrm{X}$ & $\mathrm{X}$ & $\mathrm{X}$ & \\
\hline Agriforum & $\mathrm{X}$ & $\mathrm{X}$ & $\mathrm{X}$ & $\mathrm{X}$ & $\mathrm{X}$ & \\
\hline Insight & $\sqrt{ }$ & $\mathrm{X}$ & $\sqrt{ }$ & $\mathrm{X}$ & $\sqrt{ }$ & \\
\hline $\begin{array}{l}\text { Namibia } \\
\text { Sport }\end{array}$ & $\sqrt{ }$ & $\mathrm{X}$ & $\sqrt{ }$ & $\sqrt{ }$ & & \\
\hline Otweya & $\sqrt{ }$ & $\mathrm{X}$ & $\mathrm{X}$ & $\mathrm{X}$ & $\mathrm{X}$ & \\
\hline Plus & $\mathrm{X}$ & $\mathrm{X}$ & $\mathrm{X}$ & $\mathrm{X}$ & $\mathrm{X}$ & \\
\hline Space & $\mathrm{V}$ & $\mathrm{X}$ & $\mathrm{X}$ & $\sqrt{ }$ & $\sqrt{ }$ & \\
\hline
\end{tabular}

\section{CONCLUSION}

There can be no doubt that there is increased influence over Namibian media by South African media groups. This includes major shareholdings by Naspers (over the Namibian Sun, Republikein and Allgemeine Zeitung as well as Namibia FM 99) and Telkom media (One Africa Television).

The influence also stretches to other areas such as magazine and newspaper distribution, as well as television content (such as soap operas). The increasing satellite coverage (which geographically includes Namibia), with new operators such 
as GTV, e-sat, Telkom media, etc, will also further marginalise Namibian media outlets and media production.

On the positive side there are benefits in the linkages with South African media. The Namibian Sun, for example, has gained immensely (both in terms of layout templates as well as management strategies) from the linkages with Naspers and the South African Sun newspaper.

\section{REFERENCES}

Amupala, J. 1996. The Development of Broadcasting in Namibia. Unpublished paper.

Berger, G. 2007. Media Legislation in Africa - a comparative legal survey. Grahamstown: UNESCO.

Conrad, C. \& Marshall Scott Poole 2002. Strategic Organizational Communication in a global economy. Fort Worth: Harcourt College Publishers.

Dentlinger, L. 2005. Southern Times off to slow start. The Namibian, 2005-02-28.

Dissanayake, W. 2006. Globalization and the experience of culture: the resilience of nationhood. In Gentz, N \& Stefan, K (eds). 2006. Globalization, cultural identities and media representations. Albany: State University of New York.

Duncan, J \& Seleoane, M (eds) (1998) Media and Democracy in South Africa. Pretoria: Human Sciences Research Council \& Freedom of Expression Institute.

Emdon, C. 1998. Ownership and control of media in South Africa In Duncan, J. \& Seleoane, M. (eds). 1998. Media and Democracy in South Africa. Pretoria: Human Sciences Research Council \& Freedom of Expression Institute.Telkom

Gedye, L. \& Joubert, P. 2008. Telkom Media 'in trouble’. Mail and Guardian, 200805-08:3.

Government of the Republic of Namibia (1992) Namibian Information Policy. Windhoek: Government Printers.

Hadland, A., Aldridge, M. \& Ogada, J. 2006. Re-visioning television: policy, strategy and models for the sustainable development of community television in South Africa. Cape Town: Human Sciences Research Council.

Isaacs, D. 2008. NBC caves in to demands. The Namibian, 2008-01-31.

Koenderman, T. (ed). 2008. South Africa \& SADC Media Facts. Supplement in FinWeek, 2008-05-01.

.Laden, S. 2001. Magazine matters: toward a cultural economy of the South African (print) media. In Tomaselli, K. \& Hopeton, D. (eds). Media, democracy and renewal in Southern Africa. Colordado Springs: International Academic Publishers.

Larsen, M. B.2007. Media ownership and legislation in the Republic of Namibia 1990-2007. Windhoek: MISA Namibia.

Links, F. 2006. 'We write what we like': the role of independent print media and independent reporting in Namibia. Windhoek: Namibia Institute for Democracy.

Lush, D. \& Kandjii, K.1998. Namibia In: Up in the Air? The state of broadcasting in Southern Africa. Lusaka: Panos Southern Africa. 48-76. Is this a journal reference, please clarify?

Mason, A (2001) The role of civil society in the development of democratic media in Southern Africa: the Namibian example. In Tomaselli, K. \& Dunn, H. (eds). Media, democracy and renewal in Southern Africa - critical studies on 
African media and culture. Colorado Springs: International Academic Publishers.

McMillin, D. 2007. International media studies. Oxford: Blackwell.

Pampalone, T. 2008. The Broadcaster has no clothes.Empire Magazine, 1(5). Johannesburg: Business Century

Radio Kosmos Urged to 'be original'. The Namibian, 2001-07-20.

Shivute, O. 2008. Tell the truth and nothing but the truth: Geingob. The Namibian,,2008-02-19.

The Namibian. 2002. NBC to launch French radio station. 2002-03-04.

The Namibian. 2003. One Africa TV succeeds TV Africa's failure. 2003-11-11.

The Namibian. 2008. Joint Government paper in peril. 2008-01-11.

The Namibian. 2007. Telkom Media buys into One Africa. 2007-11-23.

Wells, W., Burnett, J. \& Moriarty, S. 1998. Advertising principles and practice. $\left(4^{\text {th }}\right.$ edition). New Jersey: Prentice-Hall.

Wresch, W. 1996. Disconnected: haves and have-nots in the information age. New Brunswick: Rutgers University Press. 